DOI: https://doi.org/10.3126/njdrs.v17i0.35030

\title{
Status of Women in Nepal: A Critical Analysis of Transformational Trajectories
}

\author{
Umesh Prasad Acharya, PhD \\ Associate Professor at Central Department of Rural Development \\ Email for correspondence: umesh.acharya@cdrd.tu.edu.np
}

\begin{abstract}
Gender equations in any society are more or less anchored to cultural legacies. Nepal, being a heir to Hindu religious tradition, manifests the provision of Vedic societies in its present-day social structure, especially in gender. In the ancient times, women enjoyed equal rights and privileges as men, but with the rise of nation states, incidents of wars an conflicts multiplied for territorial expanse and security. This put male on the preference as martial and warring gender, and women started being confined to domestic responsibilities. This slowly crept into the social structure, and women have been suffering since then for lack of basic rights. The status is, however, changing because of recent political developments, that not only educated women vis-à-vis their rights, but also empowered them for various economic and social activities that contributed to their self-reliance. This article critically analyses changing value systems in the Nepalese society and the corresponding social and political transformation that has greatly altered the status of women. Much is yet to be done to bring the two genders in a equitable footing, but the gradual changes are a welcome sign towards gender equality and self-reliance.
\end{abstract}

Key words: Status of women, women empowerment, gender equality, self-reliance and social transformation

\section{Introduction}

The status of women has been a topic of discussion quite a long time in Nepal, and it is likely to prevail as a discursive issue for many more decades ahead. A scrutiny of the position of women in society is a critical factor in judging the success of any civilization. A civilization, however, draws a lot from its cultural lineage, and many times, gender equations are culturally defined. Nepalese society is, by and large, dominated by Hindu ways of thinking, and gender equations are equally influenced by Hindu cultural legacies and equations. In Hinduism, a man without the participation of his wife cannot take part in any religious ritual with perfection. Hari Priya Pathak claims, "Women enjoyed more or less the same status as men during the early Vedic Period. They underwent Upanayan Sanskaar (a ceremony to begin with formal education) just like men, were free to choose between higher studies (philosophy and logic) to become Brahmavadini, or become Sadhyavadhu to marry and look after the household and family" (228). She further writes:

In early Vedic period, the Rig Veda, child marriage is not mentioned. The girl was free to choose her match, and dowry was unknown, except that it was offered if the girl had some physical defect or the bride money was paid if the groom was less qualified (Das 1993, 58). Even widow remarriage was permissible in Vedic period (229). 
Following the Vedic line, women are often referred to the 'better-half' of men, although the term is subject of debate. But it is certain that women share equal position with men. In the past, however, men dominated the society while women were secondary actors.

This equation changed with time, when societies grew more and more martial and powerdriven and wars started becoming important for territorial expanse. Wars, due to their martial nature, prioritized brave men, and women were confined to homes. Managing families and taking care of kids became their natural obligation. This, in the long run, led to gendered bifurcations and women stopped enjoying privileges equal to their male counterparts. When we look at modern Nepalese society, the division is clearly visible, and this encompassed many aspects including politics, economic independence, property right, health issues. It can be safely argued that this is an outcome of malechild's preference in the society due to the circumstances stated above. Once again, quoting the Vedas, Pathak writes:

But the desire to get a son and not a daughter, (which became very prominent later) is very apparent through the hymns in Rig Veda, in this period too. These hymns invoking gods like Indra, Soma and Varuna during rituals, which were very common during that period, aimed at attaining wealth along with intelligent, valorous, and strong sons and grandsons. (Rg Veda. Part II 3:4:9, 3:6:1, 3:10:3, 3:13:7, 4:3:5, 4:4:11, 5:61:3). This could very well be attributed to the perpetuality of wars and the high demand of male warriors to protect the kingdoms, clans and families (229).

Since the onset of such gendered value system, women stopped enjoying even the most basic of the rights. Those rights included the safety of themselves as well. They were compelled to stay satisfied within the safely limits guaranteed by their man. They could not raise voice against their own men, as women were regarded as the possessions of men. Women were to take care of the household chores whereas men were to achieve high education and handle formal jobs to earn the bread for their families. In various part of the world, women suffered in the patriarchal and oppressed society plagued with various evils including the caste issues. Asian Development Bank, in its Gender Equality Result Case Study makes the following claim:

Women in Nepal have long experienced high levels of poverty, social exclusion, and marginalization because of their gender. For women from ethnic minorities and groups considered low caste, these disadvantages are greatly compounded. The 2013 Gender Inequality Index, reflecting gender-based inequalities in three dimensions - reproductive health, political empowerment, and economic activity_ranked Nepal 102nd out of 182 countries (1).

There are different beliefs tagged with the position of women. Oftentimes, food left over in the plates of men is considered permissible for their wives, whereas, universally, no leftover food of anyone is considered consumable for others. Women are forced to fulfill expectations albeit with a lot of sacrifices for their relationship and their family in the name of honor of their family. Women were to sacrifice their happiness and world for the welfare of their family. They were not allowed to have proper conversation with other males apart from her man. If any woman was found talking to other man, it was regarding as sin. Women were to cover their faces in South East Asia mostly in Nepal and India. They were not allowed to make any decision and were kept away from education. They were often forced to adhere to the strict stereotypical roles that were given to them but as time 
passed by, many have started to break free those rules and roles. The struggle for gender equality and women empowerment are the main concerns as the time and era have changed their priorities and value systems. As on old times women are now more educated and skilled being able to lead the family as well as companies of different level.

Empowerment must be considered from all the angles, not just in terms of commodities and economic choices. Achieving better results from empowerment efforts around the world begins with self-scrutiny. Empowerment is not just about the right to choose or have something of need or preference, but also the ability to choose and tackle something that goes against the norms and values. This can be clearer with examples like- finding a better life partner. This does not fit with the traditional approach of empowerment but the approach of encouraging the women to stay with the man who respects and loves her and does not abuse can be a way to encourage women empowerment beyond economic development. These kinds of decisions help us ensure the intended empowerment beyond needs and creating lasting chances of equality across multiple generations.

For women, no country is better developed, and no time better than any other. Though some places are clearly better for them to live in than others are, it is not always true that the relatively rich countries of the world provide better circumstances for them as women than do poorer countries. While many countries have formal provisions for sexual equality, very few governments have legislated to protect specific job and marriage right. Such laws even if they exist are nullified or blunted by social and administrative practices even they seem to challenge the traditional value system. Nowhere do women have equal rights with men. Yet women are biologically stronger. They live longer than men do, and naturally outnumber them. If there is an avenue where they do not, it is fields like war. There are instances when women are forced to migrate in search of work, or they suffered severe and systematic discrimination. In such cases, they might apparently seem weaker. Different countries have different situations regarding women and men.

In the past four decades, women's situation in western countries has undergone dramatic and remarkable changes. After the World War II, many changes took place and empowerment of women was one of them. Society realized that women are indispensable pillars for development and success; thus various policies were brought in action to promote women's empowerment. Human rights and fundamental freedoms are the birthright privileges of all the human beings. Their protection and promotion is the first responsibility of all governments. Apart from the preliminary policies such as those against female trafficking, promoting gender equality, women's rights, right to food, employment and the abolition of child marriages, more laws are promulgated and enacted to enhance the status of women all over the world. With the development in technology, women have maximum opportunities to rule the world in different ways.

Gender equality has remained a key issue for the development of women in many developed as well as underdeveloped countries. According to a survey done in 2015 in 38 countries, 65 percent people worldwide raised voice for equal rights. Support for gender equality was higher among women with higher education. Women are more likely than men to say that gender equality is highly important. People with higher level of education reported stronger support for women's right. 


\section{Theoretical Modality}

Nepal, being a multi-cultural country with more than 80 ethnic groups with their own spoken languages, morals and values, is diversified. This is both an asset as well as challenge for the country. These societal rules and responsibilities differ from one ethnic group to another, and so do their traditions. Traditions in Nepal are regarded as the blessings from ancestors. So the changes in traditions are not fully supported and accepted by the elderly population in Nepal. Moreover, the problem and the challenges faced by the Nepalese women are accentuated by the fact that Nepal is an underdeveloped country. In Nepal, the constitution of 1990 guarantees fundamental rights to all the citizens without discriminations based on ethnicity, caste, religion or sex. It also includes the right to property inheritance. The laws regarding the family laws govern marriage, divorce and property rights. Some of the provisions have severely limited the economic options and rights for women. Besides this there are some feminist principles which are presented as a challenge to discriminatory provisions. They also question provisions of privilege. They often see privileged groups as barriers towards the realization of equal right for all women beyond the fault-lines of privileged and underprivileged groups.

Feminist theories are presented as a threat to the dominant social order (Saulnier, 1996). Feminist social work practitioners rely on the theory that challenges pathologizing discourses about women that lead to inequality and oppression. Practitioners are asked to critically examine feminist theory in order to provide a suitable fit for a broad range of problems experienced by women (Saulnier, 1996). Van Den Bergh (1995) asserts the importance of socially constructed knowledge. She points at the feminists' concern with consciousness-raising as a form of knowledge production, which includes the life experiences of women. Voice - naming reality is empowering, which brings forward the importance of her last identified idea for social work practitioners - the "link between knowledge and power." She links those who control society with those who are privileged to establish what is known. It is crucial for social workers to make space for voices that have been marginalized by hierarchies of expertise in order to have a voice. The claim of the third-wave feminism is to go beyond rights and equity, although these are notable challenges in a global world.

The post-structuralist agenda, articulated decades ago, is to "remain aware of the complex ways that power, oppression, and resistance work in a media-saturated global economy so that what at first glance looks like progress might not be the change we most need, and what looks like regression might be progressive" (Heywood \& Drake, 1997, p. 23). Promoting feminist principles for social work practice is a critical priority for the future. Women face issues of equity related to economics, poverty, healthcare, childcare, and so forth. The analysis of these issues must also include race, ethnicity, socioeconomic status, and the way these factors play out on a global landscape. Strategies to create a practice framework that empowers and honors women are challenges for future.

The works reviewed in the article indicates that oppressive and gendered environments still occur. Social work must take the lead in advocacy and service needed to mitigate these issues.

\section{Methods and Materials}

This study is based on critical discourse analysis of theoretical literature and objective analysis of factual data concerning the status of women in the Nepalese society. Library and demonstrated materials, different documents published by ministry of women and health, different research articles, and other secondary information sources have been used in this paper. Some information related to 
health has been retrieved from the pertinent sources and some articles have been translated from nonEnglish sources.

\section{Discussions of Findings: Women Empowerment and Gender Equality}

The definitions of 'empowerment' vary from narrow and simple, to broad and complex conceptualizations. They can be placed on a continuum of instrumentalist development project targets and wider structural and social changes envisioned by feminist political ecologists. Development agencies that use economic interventions as a means of achieving empowerment have been accused of using the term as a buzzword for neo-liberal policies (Batliwala, 2007). The term is also often criticized for being used to represent a predictive, static outcome, rather than a process (e.g. Kabeer, 1999).

To shed light on the different facets of empowerment, it is useful to review the conceptualizations of power. The Gender Empowerment Measure (GEM) compares three indicators globally: female seats in parliament, managerial positions in the administrative and professional sectors, and income. As in the GDI, the GEM is based on secondary data, which lead to a number of problems on the reliability and validity of these indicators. Most importantly, it is worthwhile to reflect on the limited conceptualization of women's empowerment in these indices, as they exclude, for example, women's rights and opportunities of choice, as well as cultural and religious factors. Examples of tools that use more detailed indices and are based on primary data analysis include the "Measuring Empowerment Framework" by Alsop and Heinsohn (2005), particularly the concept of "Measurement of Women's Empowerment".

While in the context of Nepal, improved services to women have been facilitated by the establishment of sub-health posts at rural municipality level with VHWs and MCHWs, the general decentralization of management of health services, and efforts to ensure popular participation through female community health volunteers (FCHVs) and mothers' groups. However, while health, family planning, and population programs are primarily targeted at women, they have often ignored gender perspectives. The primary concerns in these programs have been to ensure healthy children, fertility control and safe motherhood, while women's special health needs and men's roles have been largely neglected. Even when health needs of women are mentioned at the policy level, they are lost during implementation. For example, although HMGN's family planning program includes management of infertility as one of its objectives, there is no program designed to address this issue in the family planning packages. Similarly, management of side effects, infection prevention and counseling, postpartum FP services, treatment of abortion complications, and raising awareness about late marriages form part of the strategy advocated. But no programs exist to cater to such needs. Safe motherhood targets and programs seem unaware of the pregnancy and motherhood related morbidity such as prolapsed uterus (e.g. MOH/HMGN, Annual Report, 1994/95) which is quite common in Nepal. Violence against women is also increasing as discussed. With increasing domestic violence, and the spread of venereal diseases and HIV/AIDS increasing the risk of family planning methods failing, health packages should pay immediate attention to such issues.

Gender-based violence is often reported in domestic as well as public arenas and is largely attributed to derogatory attitudes towards women, which is reinforced by low socio economic status. The maternal mortality rate of Nepalese women, associated with adolescent pregnancies and poor health services, is among the highest in the world. Recent studies reveal that one out of every thirty- 
two pregnant women die due to pregnancy and childbirth related complications. According to the Gender Development Index (GDI), socio economic conditions for Nepalese women are worse than for other South Asian women. Moreover, women remain far behind men in Nepal according to the Gender Empowerment Measure (GEM). Indeed, women's participation in politics is only one-fifth that of men and the same pattern prevails in professional occupations and administrative jobs. Although a substantial proportion of women, around 40 percent, are economically active, many are unpaid family workers involved in subsistence agriculture.

There are different philosophies about the human society since Vedic time. During Vedic world the concept of Ardhanarishwor, was considered as the symbol of perfection of human being, which is composed of half-male and half-female character. The idea goes back to the story of Shiva. Ruth Vanita explains:

Shiva is a god associated with gender trans formation, varying eroticisms, and miraculous birth. He is connected to femaleness through his ardhanarishwara (half-man, half-woman) form, and to homoeroticism through his playful transformation into a female to please his wife, Parvati, in love play. He also fathers children with the help of other males (he fathers Ayyappa with Vishnu-Mohini's help, and Kartikeya with Agni’s help) (130-31).

It is interpreted as representation of the synthesized energies of masculine and feminine of the universe. It illustrates the ideology of inseparable male and female power (Reddy, 2010). The status of women is determined by the patriarchal social system, values, and women's right preserved and protected by the state, and state policy for the development of women. Women's relative status, however, varied from one ethnic group to another. The economic contribution of women is substantial, but largely unnoticed because their traditional role was taken as for granted. It has been proved that situation of Nepalese women is too severe to compare with men.

Woman's situation is very poor in health, education, participation, income generation, selfconfidence, decision-making, access to policymaking, and human rights. The insurgency for more than 10 years between the State and the rebel has further widened this gap. Historically, women leaders in Nepal have equally contributed to establish democratic processes in Nepal. Traditionally, Nepali women had limited role in political leadership. However, they became active repeatedly and have had significant contributions in bringing political changes in Nepal. Women's participation in Nepali politics surfaced in the revolt against Rana oligarchy in 1951. For protesting against the undemocratic royal proclamation of 1960, a group of women organizations openly waved black flags in a public procession and some were imprisoned. Women's active participation in politics was noted later in the 1990 People's Movement where women from various regions and ideologies significantly contributed in the success for abolishing the one-party system and establishing the multiparty democratic system in the country. Some noted women leaders in Nepal who challenged the conventional tradition are Mangala Devi Singh, Shalaja Acharya, Sahana Pradhan and Ashta Laxmi Shakya. Others eminent leaders especially from the Peoples' Movement II are Chhaya Devi Parajuli and others. The participation of women in the People's Movement (April movement of 2006) was very high and indeed encouraging. There is no doubt that both men and women contributed equally in people's movement and protection and promotion of human rights, good governance and sustainable peace. However, men only fulfill the state positions. Nepali women have made significant contributions for the democratic processes in Nepal. However, discrimination against women still exists even within the politics. 
After the restoration of democracy in 1990, only 32 women elected as the Members of Parliaments (MPs). In general, election of 1999, which was the third election held after the restoration of democracy (1999), only 12 women out of 205 seats that is hardly six percent elected as Member of the House of Representatives. As a result, 197 women (almost 33\%) is now part of the process of Constitution making process as well as a member of the Legislative Parliament. The victory goes beyond the women's representation because these women members represent various ethnic backgrounds culture, and geographical regions of Nepal. The major issue we have to consider is women are affected differently in war, violent conflict and any human rights violation cases. There is always the cost the women pay is very high in comparison to men in any situation. However, the contribution of women always neglected. Therefore, to generate the strength of women movement for making just society, women organizations and activities have to unite and build solidarity to fight against all kinds of discrimination by promoting women in politics, and state governance system.

\section{Conclusion}

It has been realized that the status of women in Nepal has dramatically changed over time. In the ancient time, women are treated differently all over the world. In Hindu religion, women were treated as goddesses, and Nepal being a country with majority of its population coming from Hindu faith, obviously upholds the high position of women. But later on, with the coming of a nation state and structured society, women were discriminated socially, economically, politically and culturally in the Nepalese society. After the movement of 1950, some change has taken place in the condition of women. After the national movement 1989 and 2005-06, the condition of women has changed in a miraculous way. After the establishment of National Women Commission, Ministry of Women, Nepalese women organization played vital roles to change the condition of women in Nepal but still because of defective social structure, Nepalese women are facing a large number of problems into the society. How to empower them and how they would enter the mainstream of the development are still becoming burning issues in our society. After the establishment of the Department of Gender Studies at Tribhuvan University different researches have been done in the context of women development in Nepal. But there has been no change in the condition of women as expected by the political parties and civil society in the nation. Indiscriminate girl trafficking and rape are still prevalent in the society. So, further research is needed to alter the overall status of women in Nepal. Hence, it is very widely based on political, economic and social status of the different society and the women's status, which was achieved through feminist movement.

\section{Reference}

Asian Development Bank (2016). Gender equality result case study: Nepal gender equality and development of women project.

Basow, S. A., Rubenfeld, K. (2003). "Troubles talk": Effects of gender and gender-yyping. Sex Roles, 48, 183-187.

Becker, M. (2015). Constructing SSLM: insights from struggles over women's rights in Nepal.Asian Studies Review, 39(2), 247-265.

Benton, T. \& Craib, I. (2010). Philosophy of social science. New York: Palgrave Macmillan.

Leslie, H., \& Jennifer, D. (Eds.) (1997).Third wave agenda:Being feminist,doingfeminism. Minneapolis and London: University of Minnesota Press. 
Sally E. W., \& Martin F. P. (2019). Identifying paths to successful higher education for girls in the Solukhumbu district, Nepal. Mountain Research and Development, 39(3), D1-D8, (15 August 2019).

Saulnier, C. F. (1996). Feminist theories and social work: Approaches and applications (1st ed.). Binghamton, NY: Haworth.

Pandey, B. (2016). Feminist standpoint and question of women participation in decision-making, in Nepal. Dhaulagiri Journal of Sociology and Anthropology,10, 202-220.

Pathak, H. P. (2019). "Hinduism and women: Religious beliefs and practices." Research Association for Interdisciplinary Studies, 228-35.

Van, D. \& Bergh, N. (Ed.). (1995). Feminist practice in the 21st century. Washington, D.C.: NASW Press.

Vanita, R. (2004). "Wedding of two souls": Same-sex marriage and Hindu traditions. Journal of Feminist Studies in Religion, 20(2), 119-135. 